\title{
International Linkages and Environmental Sustainability: The Effectiveness of the Regime Network
}

To be presented at the Berlin Conference on the Human Dimensions of Global Environmental Change, Potsdam 2-3 ${ }^{\text {rd }}$ December 2005.

\section{Hugh Ward}

Department of Government, University of Essex

\section{Abstract}

While the literature on environmental regime effectiveness has focussed on particular regimes considered in isolation, the overall effects of the system of regimes are more relevant. First regimes are connected because they often share institutional architecture, deal with different aspects of the same problem, frame issues using similar legal and policy principles, and are subject to attempts to coordinate across issues by groups of nations, NGOs and international agencies. Thus, the network of regimes has social capital that can be applied to particular issues. Second, due to ecological interconnectedness, regimes can have both positive and negative side effects on environmental issues that they do not explicitly deal with. Allowing for political interconnectedness using concepts drawn from social network theory and for ecological interconnectedness by using broad measures of sustainability, this article argues that nations more central to the network of environmental regimes should score higher on measures of sustainability. This is because the social capital in the regime network can more easily be brought to bear on centrally-placed nations to make them cooperate and because they are more likely to be aware of negative regime side-effects. Measures of network centrality do indeed positively impact on nations' performance on four sustainability indicators. The analysis also finds that a nation's position in the general international system further positively impacts on its sustainability scores. This leads to the suggestion that the environmental regime network is supported by social capital in more general international networks.

\footnotetext{
* Thanks to Marc Levy for making available the Environmental Agreement Dataset; Eric Tannebaum for writing a programme to convert the Environmental Agreement Dataset into the format I needed to produce an affiliation network; and Jon Pevehouse for making the COW IGO dataset available in a convenient format. The data and appendices are available from the author. Correspondence: hugh@essex.ac.uk.
} 
Considerable effort has been put into constructing international environmental regimes, especially since the UN Stockholm Conference on the Human Environment in 1972. Although air and water quality have improved in some respects in rich countries, in many there are considerable problems with decoupling economic growth from emissions of greenhouse gasses, constraining waste and encouraging recycling, and preventing overuse of renewable resources such as water and fishstocks (EU Commission, 2003; OECD, 2004). In many poorer countries problems with air pollution and availability of clean water are growing along with urbanisation and industrialisation, even though there is often progress with respect to meeting basic needs (UNEP, 2002). Although considerable progress has been made over depletion of the ozone layer, the pace of advance on many other global issues has been very slow. One problem may be the single-issue focus of international environmental regimes. Many regimes displace problems, spatially, into the future, or onto other issue-dimensions. This calls into question existing ways of conceptualising their effectiveness, focusing on the current impact of individual regimes on particular problems. The central issue is whether, on balance, the system of environmental regime governance promotes sustainability.

I argue that when nations participate in particular regimes they also become part of a wider network. This network links nations and also individual regimes. It embodies social capital that may be used to encourage nations to behave sustainably. It channels broad environmental concerns and allows for issue-linkage. Through information transfer it can also help to prevent the negative side-effects of issue-specific regimes. Drawing on social network theory I measure nations’ centrality in affiliation networks created by international environmental treaties and co-membership of environmental inter-governmental organizations (IGOs). I find that nations in central positions are more likely to act sustainably, controlling for a range of other influences. This supports my 
conception of how social capital operates in the regime network. Centrality in the environmental network is highly correlated with centrality in more general international networks. I find that general centrality has greater statistical power. My interpretation is that a nation's general ties support and enhance those created by its specifically environmental commitments.

\section{The Effects of International Networks on States}

Neo-liberal institutionalism sees states as increasingly interdependent economically and politically (Keohane \& Nye, 1977), requiring international institutions and regimes to help solve a range of collective action problems (Stein, 1982; Keohane, 1984; Axelrod \& Keohane, 1985). Among the key problems are those associated with the global and regional environment (e.g. Young, 1989; List \& Rittberger, 1991; Vogler, 1995; Rosenau, 1997). Not only do regimes help nations contract to enjoy the gains from cooperation, but they also shape nations’ perceptions of their interests and of good behaviour (Young, 1999; Hasenclever, Mayer \& Rittberger, 1997: 136-211). Regimes are both a symptom of interdependence and a means whereby ties are forged between nations. Individual regimes are also linked together (Keohane, Haas \& Levy, 1993: 15-16).

Regimes may be 'nested' in some legal and institutional architecture that relates to a family of issues (Vogler, 1995: 37; Young, 1999: 183). A ‘cluster’ of different regimes may deal with different aspects of the same problem (Young, 1999: 184-185). Discourses travel across issue domains and between regimes, through borrowing, adaptation, and imposition by powerful nations (Stokke, 1998). For instance legal concepts and institutional arrangements are borrowed from other regimes (Oberthür, 2001). Groups of nations such as the G.77 and the EU attempt to coordinate across different issue-areas (Vogler, 1995: 32). Since the mid 1980s environmental NGOs have created advocacy networks that span a wide range of issues (Keck \& Sikkink, 1998: 121-163), and work has started to explore these using social network theory (Anheier \& Katz, 2005). Private 
corporations concern themselves with the interactions between trade, the environment and development and they, too, build networks to coordinate across these issues (Falkner, 2003). Finally, scientific networks interconnect issue-areas (cf. Haas, 1989). Thus the system of regimes has a structure that is not reducible to the properties of individual regimes. Why might this matter to nations' behaviour?

The notion of interconnectedness is central to theories of social capital. Interpersonal ties facilitate collective action, because obligations and expectations are created that are of help in making and enforcing deals (Coleman, 1990: 306-310). One reason is that those who renege can be excluded from other forms of reciprocity (Taylor, 1982). Trust is central to solving collective action problems that have inefficient as well as efficient equilibria. Without this form of social capital players' fears about others' intentions may lead to non-cooperation (Putnam, 1993). Norms, which may be considered a form of social capital, restrain behaviour and make it more predictable, as well as encouraging concern for others’ interests (Coleman, 1990: 310-311).

Social capital improves the chances of environmentally sustainable practices within communities (Ostrom, 1995; Pretty \& Ward, 2001). Ties between nations matter, too. There is greater scope for sanctioning non-compliance in relation to one regime when nations can withdraw their cooperation over other issues (Lohmann, 1997); and there is greater scope for getting cooperation through issuelinkage, supposing there is some heterogeneity of preference (Martin, 1995; Finus, 2001: 103-118). Thus the existence of multiple ties between nations allows sanctions and bribes to be used. Nations may avoid freeriding because of loss of their general reputation for trustworthiness, important to many relationships (Keohane, 1984). They may be concerned about knock-on effects from their freeriding that reduce the viability of the overall system of governance (Young, 1989). Thus whether a nation cooperates on a certain environmental issue does not just depend on the properties 
of the individual regime dealing with it. The network of regimes embodies social capital that may be brought to bear on nations well-tied into it, making them less likely to freeride on a particular environmental regime.

Networks have a capacity to carry information - an important aspect of social capital (Coleman, 1990: 310). Compliance with dysfunctional environmental regime rules hardly improves outcomes. If information on side effects flows freely to a nation through the network, it is less likely to agree to dysfunctional rules and it will be more alert to positive synergies. Without a connected communications network it is difficult efficiently to coordinate actions (Slikker \& Van den Nouweland, 2001: 21-29). Experimental work establishes that communication helps to activate shared norms and understandings (Ostrom, Gardener, \& Walker, 1994), and it is plausible that norms of appropriate response to environmental issues are also learnt by contact.

\section{Nations' Centrality in the Regime Network}

Talk of the network or web of interdependences created between states by membership of IGOs and by international law is a long-standing feature of IR theory (Jacobson, 1984). I make this notion more precise and operationalize it using social network theory. There is empirical evidence that ties between pairs of nations created by common adherence to international treaties (Sanders, 1986) or common membership of intergovernmental organisations (Russett \& Oneal, 2001: 157196) reduce the chances of conflict between them. Partly because the focus in these studies is on dyadic conflict, they do not adopt a network perspective that allows for indirect links. For example although Russett \& Oneal (2001: 169) talk about the network of intergovernmental organisations, to capture the effects of this on dyads they count the number of organisations of which both $a$ and $b$ are members. This is to ignore the possibility that $a$ may bring influence to bear on $b$ to sue for peace via another state, $c$. In contrast the centrality measures I discuss allow for indirect effects. In 
relation both to peace (Hafner-Burton \& Montgomery, 2006) and to trade (Ingram, Robinson \& Busch, forthcoming), an emerging literature influenced by social network theory finds that we cannot adequately understand nations' behaviour without considering the international network as a whole, supporting the network perspective adopted here.

I use two indicators for membership of environmental regimes: being a party to an international environmental treaty; and membership of an inter-governmental organisation with environmental functions. Treaty data was drawn from the Center for International Earth Science Information Network (CIESIN). I used information on 392 treaties. ${ }^{2}$ This set includes all major multilateral environmental agreements. Not all the agreements included have environmental issues among their central concerns. Nevertheless all of those included have some environmental implications and can be placed in subject categories corresponding to those used by the International Union for the Conservation of Nature Environmental Law Information System.

States can relate to a treaty in various ways under international law. The most relevant here is being a party, implying that the state has consented to be bound by an agreement that is in force. States are linked in an affiliation network (Wasserman \& Faust, 1994: 291-342) by having it in common that they are parties to an environmental agreement. Two states that are both parties to the same agreement are related by this fact: they agree to the same set of formal rules, although these may place different obligations on them; they are members of the same culture of informal rules, norms and understandings that develop as part of regimes; they interact together in negotiating and implementing the treaty and developing the regime. The network between states must be represented by a valued graph. States $i$ and $j$ with a common affiliation to at least one treaty are linked by an edge of the graph. Frequently states $i$ and $j$ will both be parties to a number of treaties. 
This number is the value of the edge linking them. Graphs can be directed, so that a link between $i$ and $j$ does not necessarily imply a link between $j$ and $i$. But this graph is undirected. From a network perspective not only are there direct links between nations but there are also indirect ones. For example, if there is an edge between $a$ and $b$ and another between $b$ and $c$, a is indirectly linked to $c$ along a path. ${ }^{3}$

For a valued, non-directed, graph the degree of a node is the sum of the values on all edges incident on it. This is taken to be a measure of the centrality of the actor in a network, because those to whom many others are adjacent are "where the action is" and are central to channels of communication (Freeman, 1979; Wasserman \& Faust, 1994: 179-180). For the IGO network this variable, regimecentrality1, increases as a function of the number of other nations nation $i$ is linked with and, for any such nation $j$, the number of treaties both $i$ and $j$ are parties to. ${ }^{4}$ I argued above that whether a nation $i$ will cooperate depends in part on the ability of other nations to threaten or to bribe it. Other things equal, the greater the number of ties $j$ has with $i$, the greater its leverage; and the greater the number of other such nations the greater the chances that this leverage will be used. Thus i’s average level of cooperation over all issues should increase with regimecentrality1.

Cooperation should also positively correlate with regimecentrality1 because central nations are likely to receive more information about environmental issues and regime side-effects and because they are more likely to be socialized into behaving sustainably through contact with others. In short,

\footnotetext{
2 The CIESIN data was a provisional version dated 19 April 2002. Neumayer (2002: 147) makes a case for excluding agreements that almost all countries have signed, whereas I am interested in measuring ties created between parties, whether the commitments are significant in themselves or not.

${ }^{3}$ As every nation can be reached along some path from every other, the network is connected and there are no separate components of the graph; and except where they include a small number of micro-states and states which are not universally recognised, dyads are adjacent i.e. there is a direct link. According to the theory of 'structural holes' (Burt, 1992), individuals who have ties that span groups that would otherwise be components possess a form of social capital, because of their control over information. This theme somewhat contrasts with that emphasised so far -- that social capital is associated with dense ties, or closure (cf. Coleman, 1990: 313-315; Burt, 2000: 379).

${ }^{4}$ Centrality measures were calculated using UCINET6. Flowbetweeness indicates what proportion of the maximum possible total information flow in the network has to pass through any given node, another measure of its centrality (Freeman, Borgatti \& White, 1991: 148). Such measures generally are very highly correlated with degree centrality but do not perform as well in the statistical analysis.
} 
central nations are more prone to be influenced by the use of international social capital to act sustainably. ${ }^{5}$

Table $\mathrm{I}^{6}$ reports an OLS model for regimecentrality1. Loggnicap is the natural logarithm of gnicap, a nation's income per-capita for the year 2000 at purchasing power parity, calculated by the World Bank; logpop is the natural logarithm of pop, a nation's population in the year 2000, included because of existing evidence that bigger countries are more likely to sign environmental treaties (Neumayer, 2002: 154); democracy is its score on the corrected Polity IV democracy index, included in the light of evidence that democracies are more likely to sign environmental agreements (Congleton, 1992: 419; Neumayer, 2002; Gates, Gleditsch, \& Neumayer, 2003). ${ }^{7}$ I expected there to be regional effects because the international system contains regional subsystems comprised of organisations that deal with regional issues, including environmental issues. The two significant regional dummies were e $u$ for member states of the European Union and asia for nation whose territory is solely or predominantly in Asia. Wealthier, more populous, democracies are more central. There is a strong, non-linear, positive relationship between the wealth of a country and regimecentrality1 (cf. Jacobson, Reisinger \& Mathers, 1986; Neumayer, 2002: 154). The picture parallels the close relationship between income per-capita and pollution regulation at the domestic level (Dasgupta et al., 2001). To avoid the possibility of spurious correlation between centrality and sustainability, I controlled for wealth, population and democracy when building the statistical models for sustainability reported below.

\footnotetext{
${ }^{5}$ Centrality can also be seen as a measure of power derived from the social network (Wasserman \& Faust, 1994: 172175). The difference in degree centrality in the IGO network of members of a dyad, a measure of the difference in their power, has been shown to negatively correlate with violent conflict between them, controlling for the capability ratio among other factors (Hafner-Burton \& Montgomery, 2006).

${ }^{6}$ Statistical results were obtained using Stata v 8.1.

${ }^{7}$ Neumayer (2002) found some variation depending on which of four measures of democracy was used and whether the scales were simplified e.g. by dichotomisation. Gates, Gleditsch \& Neumayer (2003: 37) suggest that participation is the most important component of democracy indexes in this context and that the measure of this on the PolityIV index is unsatisfactory.
} 
Table I about here

The World Directory of Environmental Organization's listing of IGOs in existence in 2001 identifies 117 organizations that had a significant environmental function, excluding subsidiary bodies of other organisations and UN agencies (Trzyna, 2001). I was able to obtain membership information for 105 of these organisations for 186 countries, either from the Directory, web addresses, or by drawing on the Correlates of War Project IGO dataset. ${ }^{8}$ I calculated degree centrality for the environmental IGO network, regimecentrality2. Table II show that this has a correlation of 0.73 with regimecentrality 1 , suggesting that the two indicators measure the same underlying concept.

Table II about here

The Kantian view is that IGOs, economic interdependence, and democracy form a mutually supportive triangle that promotes peace. The network of IGOs facilitates: deterrence of bad behaviour; mediation and problem-solving; sharing of information; and the generation of norms and trust (Russett \& Oneal, 2001: 159-165). This raises the possibility that nations' environmental record may relate to their general position in the international system, just as recent work suggests that joint membership of non trade-related IGOs increases trade between pairs of nations (Ingram, Robinson \& Busch, forthcoming). Definitions of statehood and sovereignty, norms, and rules of

\footnotetext{
${ }^{8}$ Version 2.1 of the data was used. See Pevehouse, Nordstrom \& Warnke (undated).
} 
diplomacy condition nations’ behaviour (Young, 1999). Global environmental issues challenge ideas about sovereignty by emphasising interconnectedness. Emerging norms about the proper role of the state in relation to environmental problems are beginning to shape thinking in many issuedomains, including trade and development. But if sustainability is an idea with some general currency in the international system, nations’ behaviour should also be affected by their position in networks that go beyond the specifically environmental. Moreover, a country that is generally wellnetworked might be more subject to pressure over particular environmental issues and may obtain additional relevant information. Drawing on the Correlates of War Project IGO data, I calculated degree centrality scores for nations in the affiliation network generated by common membership in the year 2000 of 396 active IGOs, centrality. ${ }^{9}$ This variable measures centrality in the general international system. As Table I indicates, it is correlated above 0.75 with measures of centrality in the environmental regime network.

\section{Conceptualising Effectiveness}

It is widely accepted that regimes vary considerably in their effectiveness and that some are notably ineffective (Young, 1989; List \& Rittberger, 1991; Underdal, 1992; Levy, Keohane \& Haas, 1993; Young, 1994; Sprinz \& Helm, 1999; Young \& Levy, 1999; Miles et al., 2001; Helm \& Sprinz, 2000). While there is little consensus about what effectiveness means and how to measure it, most authors do agree that effectiveness should be judged relative to a regime's impact on the problem it sets out to deal with (Young \& Levy, 1999; Young, 1999: 108-133; Miles et al., 2001: 4-13). At first sight this seems natural, but we should recognize the importance of direct and indirect effects, internal and external effects, and positive and negative effects (Levy, Young \& Zurn, 1995: 21; Kutting, 2000: 17-20). Although there can be positive synergies, indirect, negative, external regime

\footnotetext{
${ }^{9}$ Of the 105 environmental IGOs I used to calculate measures of centrality in the environmental regime network, 58 also appear in this list of general IGOs. With the possible exceptions of the Arctic Council, the International Council for the Exploration of the Sea, and the International Council for the Scientific Exploration of the Mediterranean Sea,
} 
effects are particularly important with respect to environmental problems (Birnie \& Boyle, 1992: 30; Kutting, 2000: 123).

Regimes carve problems up in ways that may correspond more to organisational, bureaucratic or power logics than to ecological ones (Vogler, 1995: 26-27). They may apparently solve problems only to displace them, either in time, space, or into some other part of the ecosystem. One case concerns flue-gas de-sulphurisation to reduce acid deposition. The consensus among scientists is that sulphate aerosols in the atmosphere, deriving partly from sulphur-dioxide emissions, have a net negative forcing effect on global temperature (IPCC, 2001: 8-9). Thus domestic clean-air legislation and the associated regime dealing with transboundary air pollution probably exacerbate climate change to some extent. Negative external effects have been central to attempts to foster integrated pollution control, both at the domestic level and at regional level in the EU (Weale, 1992: 93-121). Sometimes awareness leads to attempts to deal with negative external effects, such as treaties to regulate straddling fish stocks that help overcome the side-effects of policies in national waters (Stokke, 2001) or attempts to phase out some HCFCs, partly because they are powerful greenhouse gasses (Oberthür, 2001). Because of such negative external effects, although questions about whether a particular regime is effective in its own domain are certainly important, we also need to ask whether the regime-system fosters sustainability, broadly understood (Ward, Grundig \& Zorick, 2004).

\section{Measuring Sustainability}

It is possible to think of sustainability in narrow terms as environmental sustainability, focussing on preservation of ecosystems to the exclusion of human interests. However, most definitions also

these were clearly multifunctional, typically either having primary functions related to economic development or to conservation of economically important species of fish; so it was justified to include them in both sets. 
consider human welfare, conceiving sustainability as an equitable pattern of current consumption that maintains or augments the stock of capital, including natural capital, so that the life-chances of future generations are not unfairly prejudiced. Even so there are still several distinct families of meanings (Pearce, Markandya, \& Barbier, 1989: 28-50). First, it is not clear what intra-generational equity of current patterns of consumption requires. Second, there are very different accounts of what justice between generations means (Dobson, 1998: 62-84), not all of which imply the maintenance of capital, even if some weight is given to the far future (Heal, 1998). Beside natural capital there is physical capital, human capital, and social capital. Third, it is not clear whether practices should count as sustainable when they erode natural capital but substitute man-made capital. Proponents of weak sustainability assume that such substitution is generally possible, but proponents of strong sustainability argue that there are critical limits to this (Neumayer, 2003) .

In this paper I use four measures of sustainability to help establish whether results are robust. A general problem is data availability. I could not deal adequately with income inequality, although it matters to intra-generational equity and it may be causally linked with environmental quality (Torras \& Boyce, 1998). ${ }^{10}$ Another basic limitation is that, although there is reliable annual time series data on some environmental variables for rich countries (e.g. EU, 2003; OECD, 2004), coverage is patchy, time series are short and annual data is largely unobtainable for poorer countries. Because of intensive research effort and the relative ease of estimating emissions based on reliable figures on fossil-fuel consumption, relatively abundant time series data on greenhouse gas emissions exists (IPCC, 2001); and World Bank development indicators are available for significant periods. As important as these indicators are, they are hardly a broad enough basis on which to build an analysis of sustainability. Because of the lack of time series data, my analysis will be cross-sectional.

\footnotetext{
${ }^{10}$ The most complete comparative data set on income inequality is that of Deininger \& Squire (1996), but the information sometimes dates from the 1980s and some is acknowledged to be of poor quality.
} 
My first measure is derived from factor analysis of a large number of environmental and development indicators. I drew on data from Global Leaders for Tomorrow Environment Task Force (2002). I followed GLTETF in excluding micro-states with populations below 100,000, states with areas under 5000 square kilometres, and cases where environmental data was insufficient, so the analysis is based on data from around 130 countries (2002: 6). The quality of the underlying data was variable, and some use was made of imputation and data-censoring to replace missing data and to prevent data likely to be erroneously reported from skewing results. Variables are measured as close to 2002 as the available sources allow, but some figures are not fully up to date.

In creating an index of sustainability GLTETF standardised and added variables (2002). They included measures of the political capacity of countries to achieve sustainability and some indicators of their membership of environmental regimes. In a cross-sectional design such indicators are best regarded as independent variables that might help explain current variation in sustainability. Excluding such variables I was left with 45 indicators of pollution, non renewable and renewable resource use, provision for basic human needs, and conservation effort. ${ }^{11}$ I found that they cannot be summed to form a reliable additive scale, Cronbach’s Alpha only being 0. 001. Using iterated principle-factor analysis I found a smaller number of underlying dimensions, operating on the assumption that some of the variance in each indicator is unique and cannot be accounted for by the common factors (Pennings, Keman \& Kleinnijenhuis, 1999: 101-104). The first factor accounts for $59 \%$ of the common variance that the overall factor solution explains, having an eigenvalue of 12.2. The factor loadings on individual variables suggest that this factor captures a trade-off between low ecological impact and economic development, a number of measures of environmental impact and development having factor loadings with magnitudes of 0.7

\footnotetext{
${ }^{11}$ The list of variables and their definitions are available in Appendix A, available at http://www.prio.no/datasets/jpr.
} 
or above. ${ }^{12}$ This is further confirmed by correlating nations' factor scores, factor 1 , with other measures.

My second measure of sustainability is ecological footprint. Footprint is the area in hectares, in standardised units, necessary to sustain the lifestyle of an average citizen of a nation (Wackernagel et al., 2002). It measures the degree to which the citizen's consumption and investment impinges on the earth's carrying capacity. In averaging over the geographical distribution of human impacts, it ignores local hotspots where problems are intense; and it ignores the build-up of substitutes for natural capital, emphasised by proponents of weak sustainability (Opshoor, 2000; Van Kooten \& Bulte, 2000). Footprint relates to factor 1 and to measures of development. Allowing for nonlinearity, there are strong bivariate correlations between factor1, footrprint, and HDI -- a nation's score on the UN's Human Development Index. High national scores on the first factor and on footprint indicate a nation is developed and provides for the basic needs of its citizens, but it is likely to have an economic system with high impact on carrying capacity. ${ }^{13}$ Low scores on factor1 and footprint may relate to environmental sustainability and availability of natural capital to future generations, but come at the expense of current wellbeing.

My third measure of sustainability is another factor score. Given that the predominant factor is so readily interpretable, it is not surprising that on investigation rotation of the factors generated a solution that is harder to interpret and gives less insight. Nevertheless the first factor is not the only one with an eigenvalue of greater than 1 , a commonly used rule for deciding which factors are worthy of inclusion (Pennings, Keman \& Kleinnijenhuis, 1999: 104). Eventually, on the basis of eigenvalue magnitude and Cattel’s Scree test (Pennings, Keman \& Kleinnijenhuis, 1999: 105), I

\footnotetext{
${ }^{12}$ Factor loadings are available as Appendix A.

$13 \mathrm{LogHDI}$ is the natural logarithm of HDI; logftpri is the natural logarithm of footprint, and logfactor1 is the natural logarithm of (factor1+2). The correlation between logfactor 1 and $\log H D I$ is 0.942 ; that between logfactor 1 and logftpri is 0.808; and that between logftpri and logHDI is 0.835 .
} 
restricted the model to four factors. Of the three not so far considered, only the second factor is both readily-interpretable and strongly related to more than one aspect of environmental performance. High scores on factor2 indicate a country with low energy efficiency and associated forms of air pollution, shortage of water, and low water-quality.

My fourth measure of sustainability is genuine saving. Genuine saving is a sustainability indicator available from the World Bank that attempts to measure the true rate of saving in an economy, allowing for depletion of natural capital as well as investment in physical and human capital. After putting a shadow price on depletion of natural capital, this total is subtracted from net economic investment plus education spending, using the latter as a proxy for building human capital. Genuine saving measures weak sustainability, for it is based on the assumption that there are human-made substitutes for all forms of natural capital. There are questions about whether it weights present consumption too lightly; and there is a range of objections to the limited environmental data employed and the lack of attention to population growth and technical change (Neumayer, 2004; Dietz \& Neumayer, 2004; Hamilton, Atkinson \& Pearce, 1997). For some countries, the World Bank provides continuous time-series data back to 1970; but for most poorer countries the series only starts in 1995. In some cases there is considerable short term fluctuation, so I calculated gensav by averaging a county's reported genuine savings level as a percentage of its GNI over the years 1995 to $2001 .{ }^{14}$ Gensav has a bivariate correlation of $-0.44(n=108)$ with factor2, suggesting that the second factor may partly be picking up failure to achieve weak sustainability.

Control Variables and Statistical Model-Building Strategy

I expect a nation's sustainability scores to be affected by its economic performance, demographic variables, and its internal political structure and regulatory capacity, as well as being positively 
affected by its centrality in international networks. For some dimensions of environmental quality there is evidence for an 'Environmental Kuznets' Curve', whereby environmental quality first drops as a function of economic development and then increases, as richer citizens eventually demand cleanup and the structure of the economy changes to less polluting industries (Grossman \& Krueger, 1995; Torras \& Boyce, 1998; Barrett \& Graddy, 2000). This indicates the need to allow for non-linear income effects. While economic growth might provide the resources needed for cleanup, it might also be associated with rapid exploitation of natural capital. Although one form of comparative advantage for poor countries could be lax environmental regulation (Chichilinisky, 1994), the evidence for 'pollution havens' is weak, although some industries may relocate to get an easier ride (Wheeler, 2001; Clapp, 2001). Such arguments suggest the need to control for measures of the openness of the economy to trade. I assume population, population growth and population density matter because of the way they interact with growth in consumption and with attempts to reduce the environmental impact of economic activities. Some indicators entering the factor analysis relate to purely domestic environmental issues. Therefore it is important to control for capacity for domestic regulation. There are theoretical grounds to expect that authoritarian governments will have a worse environmental record than democracies, possibly because their leaders are richer and have shorter time horizons than the median voter in democracies, or because citizens in democracies are better informed and can influence outcomes. Although the empirical evidence on the impact of democracy is ambiguous, findings being sensitive to what measures of the dependent variable are employed, it seems important to include democracy scores as a control (Congleton, 1992; Midlarsky, 1998, Neumayer, 2002). ${ }^{15}$

In the light of the above discussion, I conclude that existing theory and evidence only gives rather broad and non-specific advice about what variables to include in statistical models for sustainability

\footnotetext{
${ }^{14}$ If data on gensav was missing for more than two of these years, I excluded the country concerned.
} 
and what functional forms relationships take. Moreover, I employ four rather different indicators of this complex concept so that guidance is even weaker. In the light of this, I built regressions in Table III by ‘testing down’. For each sustainability measure I started with a larger number of potentially relevant control variables together with measures of centrality. The initial list of controls derived from the considerations in the last section. In conjunction with available evidence and theory, preliminary analysis of bivariate correlations with each version of the dependent variable was used to explore functional forms of relationships, leading to some independent variables being transformed so as to allow for non-linearity. When more than one such transform seemed possibly justifiable, I chose the one maximising the explanatory power of the model. Once the initial model was built, I eliminated independent variables that were clearly not significant, checking for the stability of remaining coefficients. Testing down is justified by: i) the fact that it is more dangerous to exclude relevant independent variables than initially to include irrelevant ones, for the former leads to biased estimates, justifying starting the process with a broad range of variables where existing theory and evidence is weak; ii) the desire to build parsimonious yet powerful models, justifying eliminating non-significant variables and exploring functional forms (Kennedy, 1992: 75). Testing down does lead to variation in the variables included in models for the four sustainability indicators, as well as in the functional forms employed for some variables. Perhaps this is not surprising since the four indicators measure different aspects of such a complex and contested concept.

\section{Results from Statistical Analysis}

Each row in Table III corresponds to an indicator included in at least one final model. Data on control variables derived from the GLTETF data-base, supplemented by the World Bank

\footnotetext{
${ }^{15}$ It is possible that the relationship between wealth and environmental quality is conditional on democratic freedoms (Barrett \& Graddy, 2000; cf. Neumayer, 2002: 143).
} 
Development Indicators. In Regression 1, corresponding to the first column in Table III, the dependent variable is factor1, which I expect to fall with a nation's centrality. There are problems with multicolinearity if measures of environmental regime centrality and general system centrality are both included in the same model. I first report the version including the centrality measure with the highest t-value. In Regression 1 centrality has a significant negative impact on factor1; so general system centrality pushes down a nation's impact on carrying capacity, but is negatively associated with basic-needs provision. If centrality is replaced by regimecentrality2, the environmental regime network variable with the greatest statistical power, this indicator also has a significant negative coefficient. Table III reports this coefficient for the alternative version of Regression 1 where regimecentrality2 replaces centrality. Coefficients on other variables in this alternative regression are similar to those shown in the table and are not reported. Given the correlation between centrality in the general network and the environmental regime network is high but the former is more statistically powerful than the latter, a reasonable interpretation is that a nation's environmental ties have more impact when supported by a central position in general international networks.

Table III about here

In regression 1 Loggnicap is highly significant and has a positive coefficient. Logpop and population density, density, have positive and significant impacts; but the annual rate of population growth in 2000, popgrow, has a significant negative impact. The model in Regression 1 explains about $90 \%$ of the variance, largely because loggnicap is so powerful. The model passes the Ramsey RESET test for specification and the Cook-Weisberg test for heteroscedasticity. 
In Regression 2 the dependent variable is footprint and I expect centrality to have a negative coefficient. Here t-values are based on robust standard errors as the model suffered from heteroskedasticity. ${ }^{16}$ Centrality has a negative and significant relationship, so a citizen’s footprint is lower for nations more central to general international networks. In line with the results from regression 1 , if this variable is replaced by measures of centrality in the environmental regime network, the effects are similar but weaker, as shown in Table III. According to the coefficients on gnicap and gnicapsq, footprint increases with per-capita income until it reaches $\$ 27,600$. Capgov is a measure of the capacity of a country for environmental governance, obtained by standardising and adding a number of variables relating to quality of environmental regulation (GLTETF, 2002). Capgov has a negative although barely significant relationship, suggesting that capacity for domestic regulation may matter. ${ }^{17}$ Neither pop nor logpop are significant when added to this model, probably because footprint is a per-capita measure.

In Regression 3 the dependent variable is factor2. Centrality has a negative and significant coefficient, as expected given high scores on the second factor relate to problems with energy and water. Again if this variable is replaced by one for environmental regime centrality the effect is similar but slightly weaker. ${ }^{18}$ The results again suggest that both the environmental treaty network and the general international system matter. Growth90s, the average annual rate of growth of gdp from 1990 to 2000, has a significant negative coefficient. Cappri is a measure of private-sector responsiveness, derived by standardising and adding several environmental ratings of large companies and survey questions relating to private-sector environmental innovation (GLTETF,

\footnotetext{
${ }^{16}$ Bangladesh is a high-leverage outlier. Inclusion of a dummy for this case does not alter the results substantively. Similarly modelling outliers with dummies in regressions 3 and 4 had little substantive effect.

${ }^{17} \mathrm{Hipc}=1$ if the World Bank classifies a country as highly indebted and poor and 0 otherwise. Dserv is the percentage of the value of exports of goods and services going to debt repayment in 2000, as reported in the World Bank's development indicators Both variables had a significant negative coefficient when added to regression2, possibly explained by their acting as proxies for unmeasured aspects of poverty and underdevelopment.
} 
2002). The domestic institutional variables democracy, capgov, and cappri each have a negative significant coefficient suggesting that democracy and domestic regulatory capacity count alongside international ties in reducing scores on factor2.

Given that energy efficiency, water quality, and water quantity load heavily on the second factor, there might be a suspicion that centrality is simply acting as a proxy for the way a nation relates to regimes dealing with these issues. I recalculated treaty-centrality on the basis of 66 treaties that were coded on the CIESIN database as dealing specifically with energy efficiency, atmospheric pollution issues relating to energy efficiency such as climate change, water quality, and water quantity. This variable, enwatdeg, has a bivariate correlation of 0.61 with centrality, suggesting that nations well-networked in the overall system also tend to be well-networked in the sub-systems around energy and water. Despite this high correlation, when enwatdeg replaced centrality in Regression 3, it was not significant ( $\mathrm{t}=0.40$ ), and it had a positive coefficient.

In Regression 4 the dependent variable is gensav which I expect to be positively related to centrality. Here centrality has a positive coefficient, significant at the 95\% level. When centrality is replaced by regimecentrality1, the effect is still positive, but it is not significant at conventional levels. Thus centrality in the general international system seems to promote genuine saving. As indicated by the coefficients on gnicap and gnicapsq, the relationship between gensav and percapita income is quadratic, decreasing until $\$ 24,000$ per-capita. Trade, trade in goods as a percentage of gdp, has a significant positive relationship with gensav. Corruption, the World Bank Governance Project's control of corruption score, has a significant positive relationship, which together with the effects of democracy suggests that good governance counts positively.

\footnotetext{
${ }^{18}$ Coefficients on other variables are very similar after this substitution and are not reported here.
} 
Over the regressions shown in Table III the evidence for a direct relationship between democracy and sustainability is mixed, showing up only in the significant coefficients on democracy in models for factor2 and gensav. This is in line with the literature, discussed above, which suggests that direct effects will not always be observed. However there are indirect effects. As we saw in Table I, democracies are more central to the international system and its environmental subsystem; and states that are central have lower footprints, better scores on the second factor and higher rates of genuine saving.

\section{The Endogeneity of Network Measures}

There is a potential problem with the endogeneity of international institutions, which calls into question whether they can be seen as independent variables in explaining the success of collective action (Snidal, 1995: 52-56) or peace (Russett \& Oneal, 2001: 212-218; Oneal, Russett \& Berbaum, 2003). It is certainly possible that nations join environmental regimes when it is already easy for them to comply given the policies they have already adopted (Downs, Rocke \& Barsoom, 1995). To do so will be a low-cost way of pleasing their domestic environmental audience, or allies. This could be associated with 'lowest common denominator' regime bargaining under a quasi-unanimity rule, where the demands made on members are those acceptable to the member most loath to act after sidepayments (Ward, Grundig \& Zorick, 2001). Because the environmental network is part of a general system of ties, it is even possible that sustainability scores could influence broader measures of centrality via this reverse effect. Because of the potential endogeneity of the centrality measures, there are worries about whether OLS estimates of coefficients are consistent. However, estimation using three-stage least squares of pairs of equations, one for the sustainability measure and another for the centrality measure, give very similar results to those shown in Table III. They provide little evidence for reverse causality from sustainability to centrality. ${ }^{19}$ Time-series data on

\footnotetext{
${ }^{19}$ These results are available as Appendix B.
} 
sustainability is better to address the issue of causality, but as explained above this is not available at present.

\section{Conclusion}

We should reconceptualize regime theory to enable us to focus on the effects of the regime system and the network that it generates between nations. I have shown that social capital is a useful theoretical focus for doing this and that social network theory can be applied at the international level when carrying out empirical work. More central nations have: i) lower scores on the first factor, indicating higher environmental sustainability, though worse current basic-need provision;

ii) lower per-capita footprints; iii) lower scores on the second factor, indicating better performance in relation to energy and water problems and; iv) higher rates of genuine saving. It is difficult to disentangle the effects of the environmental network from those of general international networks, because measures of nations' centrality in these networks are highly correlated. Measures of centrality in the general network explain more variation in sustainability, though.The results are consistent with the idea that the general network position of a nation reinforces and supports the way it is positioned in the environmental regime network. This makes sense theoretically because the general network also contains social capital which can be brought to bear to make nations more cooperative over environmental issues, and because many domains of international life have been touched by the idea of sustainability, including the economic and security domains. If this interpretation is accepted, both specifically environmental and general international networks have positive effects on sustainability despite the fact that some individual regimes have negative side effects. The way that the environmental regime network interacts with general networks certainly needs to be examined further, so as to elucidate the mechanisms and processes at work employing the techniques of qualitative and comparative research. 
The literature on the Kantian Peace suggests that, along with trade and democracy, common membership of IGOs reduces the chances of conflict between nations (Russett \& Oneal, 2001). The ideas that unsustainable practices directly cause wars or lead to intra-state conflicts spilling over into wars are both controversial. Some have argued that there are links between internal conflicts and scarcity of land and other resources (Homer-Dixon, 1999) and the existence of 'lootable’ resources (Collier \& Hoeffler, 2004), although others remain sceptical (Gleditsch, 1998), find ambiguous patterns (Ross, 2004), or relatively weak effects for resource scarcity (Hauge \& Ellingsen, 1998). Yet we may be on the threshold of an era in which increasing scarcity will generate more civil wars in some regions, if their environmental problems continue to worsen exponentially. Potential scarcity of oil and water does impact on the security planning of the US and other powerful nations (Klare, 2001). Also global problems like climate change could have second-order effects, such as migration, that could generate inter-state conflict (Hirst, 2002). In the future there may come to be another leg to add to the Kantian argument: international networks promote sustainability -- hence peace. 
Anheier, Helmut \& Hagai Katz, 2005. 'Network Approaches to Global Civil Society’, in Helmut Anheier, Marlies Glasius \& Mary Kaldor, eds, Global Civil Society 2004/5 London: Sage (206221).

Axelrod, Robert \& Robert O. Keohane, 1985. 'Achieving Cooperation Under Anarchy: Strategies and Institutions', World Politics 38(3): 226-254.

Barrett, Scott \& Kathryn Graddy, 2000. 'Freedom, Growth and the Environment', Environment and Development Economics 5(4): 433-456.

Birnie, Patricia W. \& Alan E. Boyle, 1992. International Law and the Environment. Oxford: Oxford University Press.

Burt, Ronald S., 1992. Structural Holes. Cambridge MA: Harvard University Press.

Burt, Ronald S., 2000. 'The Network Structure of Social Capital', in Robert I. Sutton \& Barry M. Staw, eds, Research in Organizational Behavior, Vol. 22. Greenwich, NY: JAI (345-423).

Chichilinisky, Graciela, 1994. 'North-South Trade and the Global Environment', American Economic Review 84(4): 851-874.

Clapp, Jennifer, 2001. 'What the Pollution Havens Debate Overlooks', Global Environmental Politics 2(1): 11-19.

Coleman, James S., 1990. Foundations of Social Theory. Cambridge, MA: Harvard University Press.

Collier, Paul \& Anke Hoeffler, 2004. 'Greed and Grievance in Civil War', Oxford Economic Papers 56(4): 563-595.

Congleton, Roger D., 1992. 'Political Institutions and Pollution Control', Review of Economics and Statistics 74(4): 412-421. 
Dasgupta, Susmita; Ashoka Mody, Subhendu Roy \& David Wheeler, 2001. 'Environmental Regulation and Development: A Cross-Country Empirical Analysis', Oxford Development Studies 29(2): 203-236.

Deininger, Klaus \& Lyn Squire, 1996.'A New Data Set Measuring Income Inequality’, World Bank Economic Review 10(4): 259-287.

Dietz, Simon \& Eric Neumayer, 2004. 'Genuine Savings: A Critical Analysis of its Policy-Guiding Value', International Journal of Environment and Sustainable Development 3(3/4): 276-292.

Dobson, Andrew, 1998. Justice and the Environment: Conceptions of Environmental Sustainability and Dimensions of Social Justice. Oxford: Oxford University Press.

Downs, GeorgeW.; David M. Rocke \& Peter N. Barsoom, 1995. 'Is Good News About Compliance Good News About Cooperation?’', International Organization 50(3): 379-408.

EU Commission, 2003. A Selection of Environmental Pressure Indicators for EU and Acceding Countries. Luxembourg: EU Office for Official Publications.

Falkner, Robert, 2003. 'Private Environmental Governance and International Relations: Exploring the Links', Global Environmental Politics 3(2): 72-87.

Finus, Michael, 2001. Game Theory and International Environmental Cooperation. Cheltenham: Edward Elgar.

Freeman, L. C., 1979. 'Centrality in Social Networks: Conceptual Clarification’, Social Networks 1(2): 215-239.

Freeman, Linton C.; Stephen P. Borgatti \& Douglas R. White, 1991. 'Centrality in Valued Graphs: A Measure of Betweeness Based on Network Flow', Social Networks 13(2): 141-154. 
Gates, Scott; Nils Petter Gleditsch \& Eric Neumayer, 2003. 'Environmental Commitment,

Democracy, and Inequality', background paper for World Development Report 2003. Washington,

DC: World Bank.

Gleditsch, Nils Petter, 1998. 'Armed Conflict and the Environment', Journal of Peace Research 35(3): 381-400.

Global Leaders for Tomorrow Environment Task Force, World Economic Forum, 2002. 2002 Environmental Sustainability Index. New Haven, CT: Yale Centre for Environmental Law and Policy.

Grossman, Gene \& Alan B. Krueger, 1995. 'Economic Growth and the Environment', Quarterly Journal of Economics 110(3): 353-377.

Haas, Peter M., 1989. 'Do Regimes Matter? Epistemic Communities and Mediterranean Pollution Control', International Organization 43(4): 377-403.

Hafner-Brown, Emilie M. \& Alexander H. Montgomery, 2006. 'Power Positions, International Organizations, Social Networks, and Conflict', Journal of Conflict Resolution 50(1): forthcoming. Hamilton, Kirk; Giles Atkinson \& David Pearce, 1997. 'Genuine Savings as an Indicator of Sustainability', University of East Anglia, Centre for Social \& Economic Research on the Global Environment working paper GEC 97-03.

Hauge, Wenche \& Tanja Ellingsen, 1998. 'Beyond Environmental Scarcity: Causal Pathways to Conflict', Journal of Peace Research 35(3): 299-317.

Hasenclever, Andreas; Peter Mayer \& Volker Rittberger, 1997. Theories of International Regimes. Cambridge: Cambridge University Press.

Heal, Geoffrey M., 1998. 'Interpreting Sustainability’, in Graciela Chichilinisky, Geoffrey M. Heal \& Alessandro Vercelli, eds, Sustainability Dynamics and Uncertainty. Dordrecht: Kluwer (112137). 
Helm, Carsten \& Detlef F. Sprinz, 2000. 'Measuring the Effectiveness of International Environmental Regimes', Journal of Conflict Resolution 44(4): 630-652.

Hirst, Paul Q., 2002. 'Another Century of Conflict? War and the International System in the $21^{\text {st }}$ Century', International Relations 16(3): 327-342.

Homer-Dixon, Thomas. F., 1999. Environment, Scarcity and Violence. Princeton, NJ: Princeton University Press.

Ingram, Paul; Jeffrey Robinson \& Marc L. Busch, forthcoming. 'The Intergovernmental Network of World Trade: IGO Connectedness, Governance and Embeddedness', American Journal of Sociology.

IPCC, 2001. A Report of Working Group 1 of the Intergovernmental Panel on Climate Change: Summary for Policymakers. New York: Intergovernmental Panel on Climate Change.

Jacobson, Harold K., 1984. Networks of Interdependence: International Organisations and the Global Political System $2^{\text {nd }}$ Edition. New York: Knopf.

Jacobson, Harold. K.; William Reisinger \& Todd Mathers, 1986, 'National Entanglements in International Organisations', American Political Science Review 80(2): 141-159.

Keck, Margaret E. \& Kathryn Sikkink, 1998. Activists Beyond Border: Advocacy Networks in International Politics. Ithaca, NY: Cornell University Press.

Keohane, Robert O., 1984. After Hegemony. Princeton, NJ: Princeton University Press.

Keohane, Robert O. \& Joseph Nye, 1977. Power and Interdependence: World Politics in Transition. Boston, MA: Little Brown.

Keohane, Robert O.; Peter M. Haas \& Marc A. Levy, 1993. 'The Effectiveness of International Environmental Institutions', in Peter M. Haas, Robert O. Keohane \& Marc A. Levy, eds, Institutions for the Earth: Sources of Effective Environmental Protection. Cambridge, MA: MIT Press (3-24). 
Kennedy, Peter, 1992. A Guide to Econometrics: $3^{\text {rd }}$ Edition. Cambridge, MA: MIT Press.

Klare, Michael T., 2001. Resource Wars: The New Landscape of Global Conflict. New York: Henry Holt.

Kutting, Gabriela, 2000. Environment, Society and International Relations: Towards More Effective International Environmental Agreements. London: Routledge.

Levy, Marc A.; Oran R. Young \& Michael Zurn, 1995. 'The Study of International Regimes', European Journal of International Relations 1(3): 267-292.

Levy, Marc. A.; Robert O. Keohane \& Peter M. Haas, 1993. 'Improving the Effectiveness of International Environmental Institutions', in Peter M. Haas, Robert O. Keohane \& Marc A. Levy, eds, Institutions for the Earth: Sources of Effective International Environmental Protection. Cambridge, MA: MIT Press (397-426).

List, Martin \& Volker Rittberger, 1991. 'Regime Theory and International Environmental Management', in Andrew Hurrell \& Benedict Kingsbury, eds, The International Politics of the Environment. Oxford: Oxford University Press (85-109).

Lohmann, Susanne, 1997. 'Linkage Politics', Journal of Conflict Resolution 41(1): 38-67.

Martin, Lisa L., 1995. 'Heterogeneity, Linkage and Commons Problems’, in Keohane \& Ostrom (71-91).

Midlarsky, Manus, 1998. 'Democracy and the Environment: An Empirical Assessment', Journal of Peace Research 35(3): 341-361.

Miles, Edward. L.; Arild Underdal, Steinar Andresen, Jørgen Wettestad, Jon Birger-Skjærseth \& Elaine M. Carlin, 2001. Environmental Regime Effectiveness: Confronting Theory With Evidence. Cambridge, MA: MIT Press.

Neumayer, Eric, 2002. 'Do Democracies Exhibit Stronger Environmental Commitments? A CrossCountry Analysis’, Journal of Peace Research 39(2): 139-164. 
Neumayer, Eric, 2003. Weak Versus Strong Sustainability: Exploring the Limits of Two Opposing Paradigms. Cheltenham: Edward Elgar.

Neumayer, Eric, 2004. 'Sustainability and Well-Being Indicators', World Institute for Development Economics Research, research paper no. 2004/3.

Oberthür, Sebastian, 2001.’ Linkages Between the Montreal and Kyoto Protocols: Enhancing Synergies Between Protecting the Ozone Layer and the Global Climate’, International Environmental Agreements: Politics, Law and Economics 1(3): 357-377.

OECD, 2004. Key Environmental Indicators. Paris: OECD Environment Directorate.

Oneal, John R; Bruce Russett \& Micheal L. Berbaum, 2003. 'Causes of Peace: Democracy, Interdependence, and International Organizations', International Studies Quarterly 47(4): 371-393.

Opschoor, Johan, 2000. 'The Ecological Footprint: Measuring Rod or Metaphore', Ecological Economics 32(3): 363-365.

Ostrom, Elinor, 1995. ‘Constituting Social Capital and Collective Action', in Robert O. Keohane \& Elinor Ostrom, eds, 1995. Local Commons and Global Interdependence: Heterogeneity and Cooperation in Two Domains. Thousand Oaks, CA: Sage (125-160).

Ostrom, Elinor; Roy Gardner \& James Walker, 1994. Rules, Games, and Common-Pool Resources. Ann Arbor, MI: University of Michigan Press.

Pearce, David; Anil Markandya \& Edward B. Barbier, 1989. Blueprint for a Green Economy. London: Earthscan.

Pennings, Paul; Hans Keman \& Jan Kleinnijenhuis, 1999. Doing Research in Political Science: An Introduction to Comparative Methods and Statistics. Thousand Oaks, CA: Sage. 
Pevehouse, Jon; Timothy Nordstrom \& Kevin Warnke, undated. 'Intergovernmental Organizations, 1815-2000: A New Correlates of War Data Set', Correlates of War Project (www.correlatesofwar.org/COW2\%20Data?IGOs?IGOv2-1.htm).

Pretty, Jules \& Hugh Ward, 2001. 'Social Capital and the Environment', World Development 29(3): 209-229.

Putnam, Robert D., 1993. Making Democracy Work. Princeton, NJ: Princeton University Press.

Rosenau, James N., 1997. Along the Domestic-Foreign Frontier: Exploring Governance in a Turbulent World. Cambridge: Cambridge University Press.

Ross, Michael L., 2004. 'What Do We Know About Natural Resources and Civil War?', Journal of Peace Research 41(3): 337-356.

Russett, Bruce \& John R. Oneal, 2001. Triangulating Peace: Democracy Interdependence and International Organisations. New York: Norton.

Sanders, David, 1986. Lawmaking and Co-operation in International Politics: The Idealist Case Re-examined. London: Macmillan.

Slikker, Marco \& Anne Van den Nouweland, 2001. Social and Economic Networks in Cooperative Game Theory. Dordrecht: Kluwer.

Snidal, Duncan, 1995. 'The Politics of Scope: Endogenous Actors, Heterogeneity and Institutions', in Robert O. Keohane \& Elinor Ostrom, eds, 1995. Local Commons and Global Interdependence: Heterogeneity and Cooperation in Two Domains. Thousand Oaks, CA: Sage (47-70).

Sprinz, Detlef F. \& Carsten Helm, 1999. 'The Effect of Global Environmental Regimes: A Measurement Concept', International Political Science Review 20(4): 359-369.

Stein, Arthur, 1982. 'Coordination and Collaboration: Regimes in an Anarchic World', International Organisation 36(3): 294-324. 
Stokke, Olav S., 1998. 'Understanding the Formation of International Environmental Regimes: The Discursive Challenge', in Arild Underdal, ed., The Politics of International Environmental Management. Dordrecht: Kluwer (234-248).

Stokke, Olav S., 2001. 'Conclusions', in Olav S. Stokke, ed., Governing High Seas Fisheries. Oxford: Oxford University Press (329-360).

Taylor, Michael, 1982. Community, Anarchy, and Liberty. Cambridge University Press:

Cambridge.

Torras, Mariano \& James. D. Boyce, 1998. 'Income, Inequality, and Pollution: A Reassessment of the Environmental Kuznets Curve’, Ecological Economics 25(2): 147-160.

Trzyna, Ted, 2001. World Directory of Environmental Organizations: $6^{\text {th }}$ Edition. London: Earthscan.

Underdal, Arild, 1992. 'The Concept of Regime Effectiveness', Cooperation and Conflict 27(3): 227-240.

UNEP, 2002. Global Environment Outlook 3. Nairobi: United Nations Environment Programme.

Van Kooten, G. Cornelis \& Erwin H. Bulte, 2000. 'The Ecological Footprint: Useful Science or Politics', Ecological Economics 32(4): 385-389.

Vogler, John, 1995. The Global Commons: A Regime Analysis. New York: Wiley.

Wackernagel, Mathis; Niels B. Schulz, Diana. Deumling, Alejandro Callejas-Linares, Martin Jenkins, Valeria Kapos, Chad Monfreda, Jonathon Loh, Norman Myers, Richard Norgaard \& Jorgen Randers, 2002. 'Tracking the Ecological Overshoot of the Human Economy', Proceedings of the National Academy of Sciences 99: 9266-9271.

Ward, Hugh; Frank Grundig \& Ethan Zorick, 2001. 'Marching at the Pace of the Slowest: A Model of International Negotiations over Global Climate Change', Political Studies 49(4): 438-461. 
Ward, Hugh; Frank Grundig \& Ethan Zorick, 2004. ' Formal Theory and Regime Effectiveness:

Rational Players, Irrational Regimes', in Arild Underdal \& Oran R. Young, eds, Regime

Consequences: Methodological Challenges and Research Strategies. Dordrecht: Kluwer (151-183).

Wasserman, Stanley \& Katherine. Faust, 1994. Social Network Analysis: Methods and Applications. Cambridge: Cambridge University Press.

Weale, Albert, 1992. The New Politics of Pollution. Manchester: Manchester University Press.

Wheeler, David, 2001. 'Beyond Pollution Havens’, Global Environmental Politics 2(1): 1-10.

Young, Oran R., 1989. International Cooperation: Building Regimes for Natural Resources and the Environment. Ithaca, NY: Cornell University Press.

Young, Oran R., 1994. International Governance: Protecting the Environment in a Stateless Society. Ithaca, NY: Cornell University Press.

Young, Oran R., 1999. Governance In World Affairs. Ithaca, NY: Cornell University Press.

Young, Oran R. \& Marc A. Levy, 1999. 'The Effectiveness of International Environmental Regimes', in Oran R. Young, ed., The Effectiveness of International Environmental Regimes: Causal Connections and Behavioural Mechanisms. Cambridge, MA: MIT Press (1-32). 
Table I. OLS Regression Model for Regimecentrality1

$\mathrm{n}=141 ;$ prob $>\mathrm{F}=0.0000 ; \mathrm{R}^{2}=0.7855$

\begin{tabular}{|c|c|c|c|}
\hline & Coef. & $\mathrm{t}$ & $P>|t|$ \\
\hline loggnicap & 561.657 & $9.9 \odot$ & $\odot .0 \odot \odot$ \\
\hline logpop & 389.406 & 8.09 & $\odot . \odot \odot \odot$ \\
\hline democracy & 52.659 & 3.88 & $\odot .0 \odot \odot$ \\
\hline$e u$ & 1094.639 & 3.95 & $0.00 \odot$ \\
\hline asia & -765.385 & -4.40 & $\odot . \odot \odot \odot$ \\
\hline constant & -4562.275 & & \\
\hline
\end{tabular}


Table II. Correlations Between Centrality Measures, n=186

| regimecentrality1 regimecentrality2 centrality

regimecentrality1|

regimecentrality2| centrality

0.727

0.779

0.775 
Table III. OLS Regression Analysis of Sustainability Measures

\begin{tabular}{|c|c|c|c|c|}
\hline & $\begin{array}{l}\text { Regression } \\
1\end{array}$ & $\begin{array}{l}\text { Regression } \\
2\end{array}$ & $\begin{array}{l}\text { Regression } \\
3\end{array}$ & $\begin{array}{l}\text { Regression } \\
4\end{array}$ \\
\hline $\begin{array}{l}\text { Dependent } \\
\text { variable }\end{array}$ & factor1 & footprint & factor2 & gensav \\
\hline $\begin{array}{l}\text { Robust } \\
\text { standard } \\
\text { errors? }\end{array}$ & No & Yes & Yes & yes \\
\hline loggnicap & $\begin{array}{l}.482 \\
(20.20) * * *\end{array}$ & - & $\begin{array}{l}.334 \\
(5.23) * * *\end{array}$ & - \\
\hline gnicap & - & $\begin{array}{l}.000524 \\
(7.41)^{* * *}\end{array}$ & - & $\begin{array}{l}-.000013 \\
(-3.47)^{* * *}\end{array}$ \\
\hline gnicapsq & - & $\begin{array}{l}-9.49 \mathrm{e}-09 \\
(-4.53)^{* * *}\end{array}$ & - & $\begin{array}{l}2.73 e-10 \\
(3.35)^{\star * *}\end{array}$ \\
\hline growth90s & - & - & $\begin{array}{l}-.0453 \\
(-2.37) * *\end{array}$ & - \\
\hline trade & - & - & - & $\begin{array}{l}.00125 \\
(7.43)^{* * *}\end{array}$ \\
\hline logpop & $\begin{array}{l}.0768 \\
(3.41) * * *\end{array}$ & - & - & 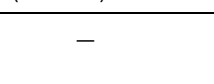 \\
\hline pop & - & - & $\begin{array}{l}9.26 \mathrm{e}-10 \\
(2.16)^{* *}\end{array}$ & $\begin{array}{l}1.57 e-10 \\
(2.57)^{* *}\end{array}$ \\
\hline popgrow & $\begin{array}{l}-.270 \\
(-8.99) * * *\end{array}$ & $\begin{array}{l}-.481 \\
(-3.53)^{* * *}\end{array}$ & - & - \\
\hline density & $\begin{array}{l}.001 \\
(5.77) * * *\end{array}$ & $\begin{array}{l}-.003 \\
(-3.12) * * *\end{array}$ & - & - \\
\hline $\begin{array}{l}\text { Centrality } \\
\text { measure } \\
\overline{B e-}--- \\
\text { regime } \\
\text { centrality } \\
\text { measure }\end{array}$ & $\begin{array}{l}\text { centrality } \\
-.000158 \\
(-4.16)^{* * *} \\
\bar{r}-\bar{g} \text { imecentr- } \\
\text { ality2 } \\
-.000547 \\
(-2.79)^{* * *}\end{array}$ & $\begin{array}{l}\text { centrality } \\
-.000327 \\
(-2.41)^{* *} \\
\bar{r} \text { regimecentr- } \\
\text { ality2 } \\
-.00124 \\
(-1.88)^{*}\end{array}$ & $\begin{array}{l}\text { centrality } \\
-.000219 \\
(-2.11)^{* *} \\
\bar{r} \text { regimecentr- } \\
\text { ality1 } \\
-.000123 \\
(-2.10)^{* *}\end{array}$ & $\begin{array}{l}\text { centrality } \\
.0000269 \\
(2.17)^{* *} \\
\bar{r} \text { regimecentr- } \\
\text { ality1 } \\
9.50 \mathrm{-}-06 \\
(1.37)\end{array}$ \\
\hline democracy & - & - & $\begin{array}{l}-.0558 \\
(-4.09) * * *\end{array}$ & $\begin{array}{l}.00468 \\
(2.86)^{* * *}\end{array}$ \\
\hline corruption & - & - & - & $\begin{array}{l}.0591 \\
(3.79) * * *\end{array}$ \\
\hline capgov & - & $\begin{array}{l}-.429 \\
(-1.72)^{*}\end{array}$ & $\begin{array}{l}-.787 \\
(-5.88) * * *\end{array}$ & - \\
\hline cappri & - & - & $\begin{array}{l}-.221 \\
(-2.03) * *\end{array}$ & - \\
\hline Constant & -3.625 & 4.087 & -.964 & -.152 \\
\hline $\mathrm{N}$ & 130 & 128 & 125 & 114 \\
\hline $\mathrm{R}^{2}$ & 0.908 & 0.819 & 0.556 & 0.489 \\
\hline
\end{tabular}

*** Significant at 99\% level; ** significant at 95\% level; * significant at $90 \%$ level. 
